\section{Combining ability and heterosis in plant} improvement

\section{Temesgen Begna*}

Ethiopian Institute of Agricultural Research, Chiro National Sorghum Research and Training Center, PO Box 190, Chiro, Ethiopia

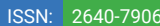

\title{
Dost
}

Received: 09 December, 2021

Accepted: 22 December, 2021

Published: 23 December, 2021

*Corresponding author: Temesgen Begna, Ethiopian Institute of Agricultural Research, Chiro National Sorghum Research and Training Center, PO Box 190, Chiro Ethiopia, E-mail: tembegna@gmail.com

Keywords: Combining ability; General combining ability; Specific combining ability; Heterosis; Heterotic groups

Copyright License: (C) 2021 Begna T. This is an open-access article distributed under the terms of the Creative Commons Attribution License, which permits unrestricted use, distribution, and reproduction in any medium, provided the original author and source are credited.

https://www.peertechzpublications.com

\section{Abstract}

Information on combining ability and heterosis of parents and crossings is crucial in breeding efforts. Genetic variety is crucial to the effectiveness of yield improvement efforts because it helps to broaden gene pools in any given crop population. The genotype's ability to pass the intended character to the offspring is referred to as combining ability. As a result, information on combining ability is required to determine the crossing pairs in the production of hybrid varieties. Heterosis is the expression of an $F_{1}$ hybrid's dominance over its parents in a given feature, as measured not by the trait's absolute value, but by its practical use. To put it another way, heterosis is defined as an increase in the character value of $F_{1}$ hybrids when compared to the average value of both parents. A plant breeder's ultimate goal is to achieve desirable heterosis (hybrid vigor). In a variety of crop species, heterosis has been widely employed to boost output and extend the adaptability of hybrid types. A crucial requirement for discovering crosses with significant levels of exploitable heterosis is knowledge of the quantity of heterosis in different cross combinations. Any crop improvement program's success is contingent on the presence of a significant level of genetic diversity and heritability. The lack of a broad genetic foundation is the most significant constraint to crop improvement and a major bottleneck in breeding operations. Heterosis is a critical factor in hybrid generation, particularly for traits driven by non-additive gene activity. To get the most out of heterosis for hybrid cultivar production, germplasm must be divided into distinct heterotic groups. Similarly, knowledge on genetic diversity is critical for hybrid breeding and population improvement initiatives because it allows them to analyze genetic diversity, characterize germplasm, and categorize it into different heterotic groupings. In general, general combining ability is used to detect a line's average performance in a hybrid combination, whereas specific combining ability is used to find circumstances where definite combinations perform better or worse than expected based on the mean performance of the lines involved.

\section{Introduction}

Combining ability analysis is one of the most effective methods for determining the finest combiners for use in crosses, whether to exploit heterosis or to accumulate productive genes [1]. It also aids in the understanding of the genetic architecture of distinct traits, allowing the breeder to build an effective breeding plan for future material improvement [2]. True understanding of genetic characteristics for various features is helpful in deciding on an acceptable breeding system, and estimations of general and specific combining ability can help with parent selection. The ability of parents (GCA) and hybrids (SCA) to combine traits is used to reveal the nature of gene activity involved in the inheritance of features [3].
Combining ability analysis is particularly important in crosspollinated crops since it aids in the identification of probable inbred parents for hybridization. Such research also aids in determining the nature and amplitude of various types of gene action influencing the manifestation of quantitative economic features [4].

There are two types of combining abilities examined in biometrical genetics: General Combining Ability (GCA) and Specific Combining Ability (SCA) (SCA). General combining ability is a measure of additive gene activity that relates to the average performance of a genotype in a series of hybrid combinations, whereas specific combining ability is the performance of a parent in a specific cross in reference to general 
combining ability [5]. Plant breeding strategies that result in hybrid selection require a certain level of heterosis as well as a specified combining capacity [6]. Within a breeding population, the relative impact of additive (GCA) and non-additive (SCA) gene activity is critical in determining which breeding strategy will most effectively improve the performance of the traits of interest [7]. General combining ability is linked to the genes' additive effects, whereas specialized combining ability is linked to the genes' dominance and epistatic effects (non-additive effects). However, Rojas \& Sprague [8] found that, in addition to dominance and epistasis, SCA variation includes aberrations due to genotype-environment interactions.

General and specific combining ability impacts, as well as breeding for hybrid and open-pollinated types, are crucial markers of the potential inbred lines in hybrid combinations. Breeders face the challenge of selecting parents and crosses for both quantitative and qualitative qualities in crop development initiatives. Plant breeders typically utilize combining ability tests to analyze the nature of gene action involved in the inheritance of specific traits and to evaluate parental lines for their usefulness in crosses. Crop yield increase necessitates a thorough understanding of the combining capacity of available parents for hybridization programs, as well as the nature of gene action involved in the expression of economically important quantitative features $[9,10]$. The additive portion of the total variance is included in the variance for general combining ability, whereas the non-additive fraction of the total variance is included in the variance for specific combining ability, which is caused by dominance and epistatic deviations $[9,11]$. Specific combining ability is a key measure of an inbred line's ability to produce superior hybrid combinations [12].

For further crop improvement, understanding the extent and pattern of variability, particularly genetic variability, present in a population of a given crop is critical. This knowledge would aid in the development of an effective breeding strategy for further genetic improvement of crop plants in terms of yields and other traits. Exploiting genetic heterogeneity in any crop species is thought to be vital for improving grain yield and other economically significant features genetically [13]. Heterosis has been extensively studied and used to improve various quantities and quality features in many crops [14]. For the development of a good commercially viable crop variety, heterosis and combining ability are required. Information on heterotic patterns and combing ability across germplasm is critical for maximizing hybrid development effectiveness [15]. In crop breeding, the phenomenon of heterosis has been extensively explored, resulting in large yield increases. When the parents come from separate populations of the same species, it's called heterosis; when the parents come from other species, it's called hybrid vigor [16].

Heterotic groups should be employed as the basis for cross-breeding, according to Melchinger and Gumber [17]. The heterotic group is a population with a lot of genetic variation and a lot of combining ability that is categorized based on breeding criteria. Heterosis is a complicated biogenetic phenomenon that manifests itself in the performance of hybrid offspring as a result of a combination of numerous elements.
The dominance and overdominance theories, which are based on allelic interactions, and epistasis, which is based on nonallelic interactions, are two classic hypotheses for the genetic mechanisms underlying heterosis. Heterosis is a phenomena in which the offspring of different types of a species or crosses between species have higher biomass, development speed, and fertility than both parents. Heterosis is a critical factor in hybrid generation, particularly for traits driven by non-additive gene activity. When related or unrelated genotypes from the same or separate populations are crossed with genotypes from other genetically distinct germplasm groups, they show similar combining capacity and heterotic response. As a result, heterotic grouping is the process of identifying germplasm groups that are genetically unique but yield superior hybrids when crossed. Heterotic patterns have a significant impact on crop improvement because they influence the type of germplasm utilized in hybrid breeding programs for a long time (Melchinger and Gumber [17].

To get the most out of heterosis for hybrid cultivar production, germplasm must be divided into distinct heterotic groups. Similarly, knowledge on genetic diversity is critical for hybrid breeding and population improvement initiatives, as it allows them to analyze genetic diversity, characterize germplasm, and divide it into heterotic groups [18]. Heterotic groups are made up of genotypes that do well when mixed with genotypes from another heterotic group [19]. Plant breeders have been classifying germplasm into separate heterotic groupings and identifying acceptable parents for crosses using genetic and morphological performance $[20,21]$. To get the most out of heterosis for hybrid cultivar development, it's crucial to divide germplasm into separate heterotic groups. Similarly, knowledge on genetic diversity is critical for hybrid breeding and population improvement initiatives because it allows them to analyze genetic diversity, characterize germplasm, and categorize it into different heterotic groupings [18]. Heterotic groups are made up of genotypes that cross well with genotypes from another heterotic group [18]. Plant breeders have been classifying germplasm into separate heterotic groups and identifying acceptable parents for crosses based on genetic and morphological performance $[20,21]$.

A need for producing meaningful heterotic patterns among germplasm lines is the efficiency with which germplasm lines are assigned to heterotic groups. The discovery of unique heterotic groups should aid in the generation of exceptional hybrids and increase the efficiency of hybrid development programs [22]. Genetic distance estimates are essential because they aid in the assignment of genotypes to heterotic groups in hybrid formation resulting from various inter-group crossings [22]. Information on genetic diversity and heterotic groups is particularly valuable to both inbred line development and plant breeders in terms of utilizing their germplasm more effectively and consistently by utilizing complementing lines that maximize the outcome of hybrid breeding operations [23]. As a result, the review's goals were to better understand the function of combining ability and heterosis in crop plant improvement through the development of new superior hybrid varieties that maximize crop plant genetic production potential. 


\section{Literature review}

Combining ability in crop improvement: The breeding utility of parental lines to produce hybrids is referred to as combining ability. It aids in the selection of parents and their use in breeding programs to produce superior hybrids. Sprague and Tatum [1] established the concept of combining ability in maize, and it has since been applied successfully in other research. The general combining ability effect is determined by additive gene action and is used to indicate hybrid performance in general terms, whereas the particular combining ability effect is determined by dominant gene action and is used to show hybrid performance in specific ones. These variance components are used by breeders to detect gene action and estimate the genetic potential of parents in hybrid pairings. Breeders could use the information of combining ability and gene activity to more effectively identify potential parents, develop breeding methods, and choose promising genotypes from segregating populations to boost productivity. Knowledge of the genetic system that controls quantitative features is essential for developing an effective selection program using the right mating design. Knowledge of genetic action, heritability, and genetic variability is beneficial to plant breeders since it allows them to develop effective crop breeding strategies.

Combining ability in crops leads to the discovery of parents with high Specific Combining Ability (SCA) effects and the location of cross combinations with high GCA effects [24]. Higher particular combining ability values imply dominance gene effects, whereas higher general combining ability effects indicate a bigger involvement of additive gene effects governing the characters, according to combining ability study of different characters. Epistasis gene effects may play a substantial influence in the genetic of characteristics if both the general and specific combining ability values are not significant [1]. One of the criteria for a successful breeding program in selecting genotypes with desirable features is knowledge of the nature and extent of variability in a population. The impacts of General Combining Abilities (GCA) and specific combining abilities (SCA) in hybrid combinations are crucial indications of inbred line potential value. Differences, in general, combining skills effects have been attributed to additive, additive $\mathrm{x}$ additive, and higher-order interactions of additive genetic effects in the base population, whereas non-additive genetic variance has been linked to differences in specific combining abilities effects [25].

Because of the extensive usage of hybrid cultivars in many crops, the notions of general and Specialized Combining Abilities (SCA) have become increasingly essential to plant breeders [26]. The examination of crossings between inbred lines is a crucial stage in the production of hybrid crop types. Specific Combining Abilities (SCA) evaluate the average performance of certain hybrid combinations compared to the parental lines and is the result of dominance, epistatic deviation, and genotype environment interactions; General Combining Abilities (GCA) characterizes the average performance of a set of hybrid combinations and is primarily the result of additive gene effects and additive interactions;
General Combining Abilities (GCA) characterizes the average performance of a set of hybrid combinations and is primarily the result of additive gene effects and additive [27]. Parents with a high GCA effect have greater adaptability and are less affected by the environment [28]. Because better qualities do not always pass down to offspring [27], evaluating combining ability is more trustworthy than evaluating line performance in general. Line tester analysis, top-cross testing, single-cross tests, poly-cross tests, and diallel mating are all examples of combining ability tests that can be used to select superior parental lines for creating heterotic hybrids [29]

\section{General and Specific Combining Abilities}

Specific Combining Ability (SCA) is the departure of the performance of crossings from the average general combining ability of two parental lines, whereas general combining ability (GCA) is the mean performance of a genotype when crossed with a series of other genotypes. Crop breeders typically utilize combining ability analyses to choose parents with high General Combining Ability (GCA) and hybrids with high Specialized Combining Ability (SCA) effects [30]. Understanding the genetic potential of a population and deciding on the breeding strategy to be used in a given population requires knowledge of the nature and magnitude of gene action [31]. The efficient transmission of desired genes from selected parents to their offspring necessitates a thorough understanding of gene function [25]. Mating designs such as diallel [32] and line tester [2] provide trustworthy information regarding a parent's general and specialized combining abilities, as well as their cross combinations. The most fundamental prerequisite for crop improvement is the identification of acceptable parents that can combine well and produce desirable hybrids.

The average contribution of inbred lines to hybrid performance in a series of hybrid combinations is known as General Combing Ability (GCA). An inbred line's general combing ability is assessed by crossing it with other inbred lines and comparing the single cross progenies' overall performance. The additive gene activity impacting a genetic trait in such a way that each boosts the trait's expression is referred to as general combining ability. The general combining ability variance estimates additive genetic variance, which is necessary for narrow sense heritability estimation [32]. General Combining Ability (GCA) is linked to the breeding value of the parents and is linked to additive genetic effects, whereas Specialized Combining Ability (SCA) is linked to non-additive genetic effects, primarily dominance, or epistatic effects [33]. The contribution of an inbred line to hybrid performance in a cross with specified inbred lines, as compared to its contributions in crossings with an array of specified inbred lines, is referred to as specific combining ability. It suggests that non-additive gene activities are primarily determined by dominance.

It's because the heterozygote phenotype differs from the average of the two homozygotes' phenotypic values [34]. Specific combining ability is an important component of hybrid performance since it is a non-fixable component of genetic variation. The selection criterion is based on the parents' general combining ability impacts. Because high-mean-value parents 
may not always be able to pass on their superior features to their offspring, it is vital to assess their compatibility in order for them to express their own high performance in hybrids involving them. High specific combining ability effects coming from crosses between parents that are both good general combiners (good GCA) can be attributed to additive gene activity. The beneficial additive effects of the good general combiner parent and epistatic effects of the poor general combiner, which fulfills the favorable plant feature, may be attributed to the high specific combining ability effects produced from crosses involving good and poor general combiner parents. High particular combining ability effects displayed by low crossings could be owing to a dominance kind of non-allelic gene interaction causing over dominance, making it unfixable. Specific combining ability is used to identify cross combinations with improved performance, whereas general combing ability is used to evaluate the contribution of an inbred line to hybrid performance [1].

For a certain attribute, general combing ability is calculated as the positive or negative departure of a genotype's mean offspring performance from the grand mean of all offspring included in the mating design. Specific combining ability is defined as the deviation of hybrid combination performance from the performance expected on the basis of the general combing ability of the parental inbred lines, while general combing ability is primarily caused by additive effects. In hybrid breeding, a specific mix of inbred lines is chosen from among several viable combinations to produce the best $\mathrm{F}_{1}$ performance. As a result, inbred lines with the best particular combining ability are chosen as parental lines. Dominance, over-dominance, and other non-additive gene effects determine specific combining abilities. A high estimate of general combing ability indicates stronger heredity and fewer environmental effects, implying higher selection success. The fixable and heritable component of genetic variance is represented by general combing ability effects, which have a direct relationship with narrow-sense heritability and homozygosity [28]. Because of the additive action of genes, the selection is useful for generating maximum genetic gain, whereas specific combining ability represents the non-fixable and non-heritable component of genetic variance.

Heterozygosity and heterosis are indicated by specific combining ability. Maximum genetic increase was obtained through heterosis breeding rather than selection, and dominance and epistasis were the driving forces [28]. The precise understanding of gene activity involved in determining the various traits is critical to a successful and sound breeding program. It is stated that if the general combing ability variance is higher, the characteristic is more likely to be controlled by additive gene action, whereas if the specific combining ability variance is higher, the character is more likely to be controlled by non-additive gene action. If the ratio of general combing ability to specialized combining ability variances for the supplied qualities is less than unity, non-additive gene action is more important than additive gene action, and heterosis breeding is recommended to take advantage of non-additive variance [35]. In general, GCA is the consequence of additive gene effects, whereas SCA is the result of dominance and epistasis-induced deviations from additive gene action [36] The GCA is the primary effect in statistical terms, whereas the SCA represents an interaction effect [36].

GCA is caused by additive gene effects and additive $\mathrm{x}$ additive epistasis and it is potentially fixable. Specific Combining Ability (SCA), on the other hand, is a non-fixable trait caused by non-additive gene effects such as dominance, epistasis, or both [37]. The primary basis for starting the hybrid program is the presence of non-additive genetic diversity [38]. Information on per se performance, combining ability effects of parents and hybrids, and the quantity of gene action involved in the inheritance of quantitative traits are vital for establishing a yield improvement program in crop [39]. The general combining ability effect is utilized to choose the best parents for crosses. The level of heterosis expected as well as the specific combining ability effect on heterotic hybrid selection. Combining ability is a useful tool for identifying the best combiners that can be used in crosses to exploit heterosis or accumulate fixable genes and obtain desirable segregates. It also aids in understanding the genetic architecture of various characters, allowing the breeder to create an effective breeding plan for future up-gradation of existing materials.

Hybrid breeding procedures necessitate an expected level of heterosis as well as a certain combining ability. Breeders frequently encounter the difficulty of selecting parents and crosses when creating high-yielding crop plant varieties. Combining ability investigations are valuable for determining the nature and amount of various types of gene action involved in the development of quantitative traits, as well as for selecting ideal parents for effective hybridization projects [1]. Combining ability aids in determining the gene action involved in yield control components. Variances, in general, combining ability (GCA) represent additive gene action, whereas variances in Specialized Combining Ability (SCA) reflect non-additive gene action. It aids in the selection of superior parents for the development of superior hybrids and takes advantage of genetic variation. Genetic variety is required to generate superior kinds with unique genetic composition, therefore choosing the right parent is critical. Grain yield is a complicated quantitative attribute that results from the action and interaction of several yield component characters. A solid understanding of the genetics of yield and its related properties is useful in making selection decisions and efficient management of breeding material for an effective breeding program targeted at improving complicated traits such as yield.

Furthermore, understanding the type and size of gene effects affecting the inheritance of agro-morphological features linked to crop productivity can aid in the formulation of an effective and efficient breeding program. The impacts of general combining ability (GCA) and Specialized Combining Ability (SCA) are highly useful genetic parameters for determining the next phase of breeding projects. The GCA effect indicates genes with largely additive effects, whereas the SCA effect indicates genes with dominance or epistatic effects, and strong GCA effects are mostly attributable to additive gene effects or additive interaction effects. According to Patial, et 
al. [40], combining ability provides useful information on parent selection in terms of projected hybrid and progenies performance. Performances do not always reveal if a parent is a good or bad combiner. As a result, data on the type of gene effects and how they manifest themselves in terms of combining ability is required. By finding potentially superior parents and hybrids, combining ability aids in defining the pattern of gene effects in the expression of quantitative traits [12].

For effective breeding and selection, understanding gene function and associated trait expression is critical [41]. Combining ability study aids in the identification of superior parents for breeding programs or prospective cross combinations for cultivar development. Specific combining ability (SCA) is the relative performance of a cross that is associated with non-additive gene action, predominantly contributed by dominance, epistasis, or genotype environment interaction effects, and is directly related to the breeding value of a parent and is associated with additive genetic effects, whereas General Combining Ability (GCA) is directly related to the breeding value of a parent and is associated with additive genetic effects, whereas General Combining Ability (GCA) is directly related to the breeding value [8]. As a result, both GCA and SCA impacts are significant inbreeding population selection and development [42].

Combining ability analysis is one of the most powerful tools for estimating combining ability variation and effects in order to pick desirable parents and crosses for heterosis exploitation. For estimating genetic control of a certain trait, ability variance is frequently combined. Estimates of additive and non-additive gene action obtained using this technique may be valuable in establishing the commercial viability of heterosis and pure line isolation. Gene action is a theory that evaluates allelic interactions for characteristics that show phenotypic behavior and lead to perfect trait selection.

\section{Heterosis in crop improvement}

Heterosis refers to a hybrid's ability to outperform its parents in terms of productivity, growth, development, and resistance [43]. One of the most significant achievements in plant breeding is the use of heterosis in hybrid breeding [44]. Heterosis is a critical factor in hybrid generation, particularly for traits driven by non-additive gene activity. Melchinger and Gumber [17] developed the concept of heterotic groups and patterns, defining a heterotic group as "a group of related or unrelated genotypes from the same or different populations that show similar combining ability and heterotic response when crossed with genotypes from other genetically distinct germplasm groups." As a result, heterotic grouping is the process of identifying germplasm groups that are genetically unique but yield superior hybrids when crossed. Heterotic patterns have a significant impact on crop improvement because they influence the type of germplasm utilized in hybrid breeding programs for a long time [17].

To get the most out of heterosis for hybrid cultivar production, germplasm must be divided into distinct heterotic groups. Similarly, knowledge on genetic diversity is critical for hybrid breeding and population improvement initiatives, as it allows them to analyze genetic diversity, characterize germplasm, and divide it into heterotic groups [18]. Heterotic groups are made up of genotypes that do well when mixed with genotypes from another heterotic group [19]. The availability of heterotic groups and patterns for exploitation of grain-yield heterosis determines the success of a hybrid breeding effort. A need for producing meaningful heterotic patterns among germplasm lines is the efficiency with which germplasm lines are assigned to heterotic groups. The discovery of unique heterotic groups should aid in the generation of exceptional hybrids and increase the efficiency of hybrid development programs [22]. Genetic distance estimates are essential because they aid in the assignment of genotypes to heterotic groups in hybrid formation resulting from various inter-group crossings [22].

Information on genetic diversity and heterotic groups is particularly valuable to both inbred line development and plant breeders in terms of utilizing their germplasm more effectively and consistently by utilizing complementing lines that maximize the outcome of hybrid breeding operations [23]. $\mathrm{F}_{1}$ hybrids between particular combinations of parental lines perform better than the parental lines in plants; the $\mathrm{F}_{1}$ hybrids have hybrid vigor or heterosis. The availability of genetically complementary parents and families, as well as the level of heritability of economic features, are both important factors in the formation of breeding populations and hybrid types [45].

\section{Classification of heterosis}

Average heterosis: In quantitative genetics, mid-parent heterosis refers to a hybrid's superiority over the mean of its parents [36]. Average heterosis or relative heterosis occurs when the hybrid outperforms the mid-parent [46]. On the basis of the mid-parents, the average heterosis in the crosses was calculated. Several researchers have determined it for a variety of agronomic and physiological parameters in diverse crops.

Heterobeltiosis: Blum, et al. [47] defined heterosis as the hybrid's advantage over the best parent, as measured in comparison to the superior or a better parent. The dominance or overdominance of the hybrid over the better parent resulted in its superiority. The degree of heterosis provides the simplest and easiest measure of genetic diversity and gives a preliminary idea about the likely gene action involved in determining a particular character. Parent versus crosses performance is probably the most basic comparison in quantitative inheritance, and the degree of heterosis provides the simplest and easiest measure of genetic diversity and gives a preliminary idea about the likely gene action involved in determining a particular character [48]. For various crop traits, several authors reported heterosis over better parents.

Standard heterosis: Standard heterosis refers to a hybrid's higher performance in terms of desired features above a standard commercial hybrid variety [49]. It is also known as economic heterosis and has practical significance in plant breeding. The 
commercial value of a hybrid would be determined mostly by how well it performed in relation to the best commercial variety of the crop species in question. Standard heterosis is the most essential from a practical standpoint since it aims to generate desired hybrids that outperform existing highyielding commercial varieties [49].

\section{Heterotic grouping and heterotic pattern}

When related or unrelated genotypes from the same or separate populations are crossed with genotypes from other genetically distinct germplasm groups, they show similar combining capacity and heterotic response [17]. Heterotic grouping is the process of identifying genetically diverse groups that produce superior hybrids when crossed based on morphological per se performance and genetic relationship [21]. Heterotic grouping identifies suitable hybrid parents by combining ability information $[50,51]$. Based on specific combining ability (SCA) effects of grain yield [52] and heterotic grouping based on General Combining Ability (GCA) of multiple traits (HGCAMT), this approach of classifying existing germplasm into various heterotic groups and identifying eligible parents for crosses $[50,51]$.

Any breeding program targeted at hybrid production must start with the identification of inbred lines with a strong combining ability [53,54]. As a result, information on combining ability-based heterotic grouping can assist breeders in choosing parents for crosses. To get the most out of heterosis for hybrid cultivar development, germplasm must be assigned to different heterotic groups. Similarly, knowledge on genetic diversity is critical for hybrid breeding and population improvement projects, which use it to analyze genetic variety and categorize individuals into heterotic groups [18]. It is preferable to organize the germplasm into heterotic groups for an efficient hybrid breeding effort [55].

The key to ensuring sustained genetic gain in hybrid breeding is to broaden the genetic foundation of heterotic pools. The heterotic grouping of parental lines and identification of their combining ability aided in the selection of parents and breeding tactics for effective hybrid creation. Studies of germplasm combining capacity and heterotic grouping improve its use inbreeding and the selection of suitable parents for superior hybrid combinations [51]. Crosses between inbred lines from genetically dissimilar groups are likely to have higher degrees of heterosis than crosses between lines from genetically related groups [56]. A heterotic pattern is a set of heterotic groups, which might be populations or lines, that exhibit high heterosis and, as a result, high hybrid performance in their crossings.

The notion of heterotic patterns is essential because it aids breeders in selecting parents for line development and testers in evaluating the combining capacity of newly generated inbred lines, simplifying germplasm administration and organization [57]. Heterotic groups and patterns assist breeders in making more efficient and consistent use of their germplasm by utilizing complementing lines to maximize the results of a hybrid breeding effort. In order to make use of heterosis for hybrid formation, germplasm must be assigned to different heterotic groups and patterns. Once heterotic groups and patterns have been identified, a high number of hybrid combinations can be created in a short period of time due to the grouping of lines into distinct clusters, which prevents the generation of unneeded hybrids from heterotic patterns.

\section{Genetic basis of heterosis}

A positive association between parental divergence and the estimated degree of heterosis is predicted by quantitative genetics theory [58]. However, the evidence for this correlation to date is inconclusive, and the capacity to predict heterosis levels based on genetic distance between parents varies with different features and crops [59]. Genetic ideas are one of the oldest and most well-accepted explanations for heterosis [58]. Heterosis can be caused through dominance, overdominance, or epistasis, according to quantitative genetic theory. The three theories have been thoroughly studied utilizing phenotypic data as well as molecular marker-assisted QTL mapping [60]. The dominance theory, suggested by Davenport [61] and supported by Bruce [62], Jones [63] and Collins [64], mentions the influence of dominant positive alleles disguising negative recessive alleles as the explanation for a hybrid's superiority [36].

According to the dominance hypothesis, the superior performance of hybrids is due to the hiding of harmful recessive genes. The harmful consequences of recessive alleles are hidden by dominant alleles in a heterozygous state. As a result, heterosis is caused by dominant alleles masking the deleterious effects of recessive alleles. Inbreeding depression, on the other hand, is caused by recessive alleles that become homozygous as a result of inbreeding. As a result, according to the dominance hypothesis, heterozygosity is not the result of heterozygosity, but rather of the dominant alleles preventing the expression of detrimental recessives. The rationale for a hybrid's supremacy is the influence of dominant positive alleles disguising undesirable recessive ones [36]. Similarly, inbreeding depression is caused by the homozygosity of recessive alleles, which have negative consequences [34]. East [65] and Shull [66], proposed the overdominance theory, which claims that heterosis is caused by the heterozygous situation. Heterozygotes of the loci are superior to both homozygotes, according to the overdominance hypothesis. As a result, heterozygosity is both necessary for and the cause of heterosis

The hybrid plant with the greatest number of heterozygous loci is the most vigorous [67]. There are no obvious circumstances in which the heterozygote outperforms the two homozygotes. This has been the most common criticism to the overdominance theory being widely accepted. However, there is no question that heterozygotes are superior to homozygotes in some genes [34]. Quinby [68], postulated that heterosis could be caused by a complementary interaction between recessive and dominant alleles. The most critical factor in heterosis of yield, number of grains per panicle, and grain weight is over dominance. According to the overdominance hypothesis, heterozygotes are superior to both homozygotes in at least some of the loci. As a result, heterozygote Aa would outperform both homozygotes AA and aa. 
As a result, heterozygosity is required for heterosis, whereas homozygosity caused by inbreeding causes inbreeding depression. According to the overdominance hypothesis, the heterozygous genotype has an intrinsic advantage over the two homozygous genotypes. The epistasis hypothesis credits heterosis to epistatic interactions between non-allelic genes, while the overdominance hypothesis implies overdominant gene activation at numerous loci. The epistasis hypothesis explains the observed heterosis as a result of locus interaction. Because it is difficult to evaluate inbred lines in various cross combinations, accurate single-cross performance prediction is critical in hybrid breeding. Several methods for predicting phenotypic data with co-ancestry coefficients calculated from pedigree records or marker data have been proposed [69]. Furthermore, genomic selection based on dense molecular marker profiles has the potential to help breeders choose the most promising hybrids for field testing [67] Figure 1.

The sum of gene effects $(A, B, A+B)$ is a phenotype. (a) The dominance model, according to which dominant alleles (A and $\mathrm{B}$ ) inhibit or complement recessive alleles ( $\mathrm{a}$ and $\mathrm{b}$ ). (b) The overdominance model, in which heterozygosity (B1/B2) at a critical locus contributes to heterosis, resulting in higher performance. Non-allelic genes (A2 and $\mathrm{B} 1$ ) inherited from the paternal lines interact and contribute to heterosis in the epistasis paradigm.

Heterosis is shown in $\mathrm{F}_{1}$ hybrids produced by crossing two inbred parents that perform better. The nature and magnitude of heterosis over mid-parent, heterobeltiosis, and economic heterosis present in genetic stocks influence the choice of parents for effective hybridization. The positive or negative reaction of heterosis is largely determined by the breeding aims and the type of crops employed. Heterosis has contributed greatly to enhanced crop productivity and is the foundation of global agribusiness worth billions of dollars Figures 2,3.

Dominant gene action is recognized when the performance of a heterozygote is not the mean of that of its two homozygous parents.

\section{Conclusion}

The ability of cultivars or parents to combine with one another during the hybridization process so that desired genes or features are passed down to their progenies is referred to as combining ability. It refers to a genotype's ability to pass on better performance to its offspring. The variance due to General Combining Ability (GCA) and variance due to Specific Combining Ability (SCA) can be separated into two categories (SCA). Specific combining ability describes those cases in which certain hybrid combinations do relatively better or worse than what would be expected based on the average performance of the parent, and is regarded as an estimate of non-additive gene action such as dominance and epistasis. General combining ability is defined as the average performance of a parent in a hybrid combination and is primarily recognized as a measure of additive gene action, whereas general combining ability describes those cases in which certain hybrid combinations do relatively better or worse than what would be expected. Combining ability analysis aids in the identification of parents with high General Combining Ability (GCA) effects and cross combinations with high Specialized Combining Effects (SCA) for commercial heterosis and pure line isolation among heterotic hybrid progenies.

In crops, heterosis appears in the progeny of inbred lines with a high specific combining capacity. Heterosis is a (a) Dominance model

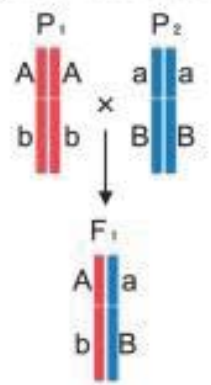

(b) Overdominance model

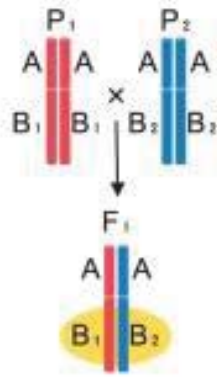

(c) Epistasis model

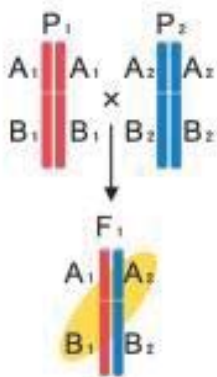

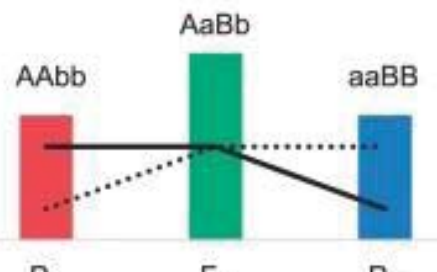

P,
$\mathrm{P}_{2}$

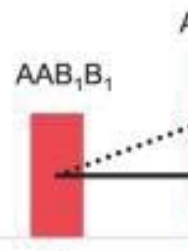

$P$,
$A \mathrm{AB}_{1} \mathrm{~B}_{2}$

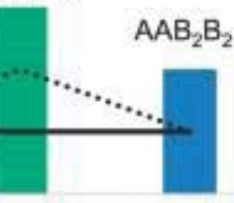

$\mathrm{F}$,
$P_{2}$

phenotype

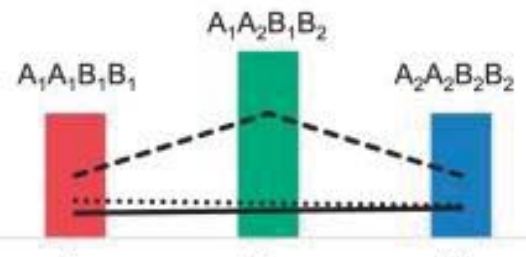

P,
$P_{2}$ 


$$
P_{1}=P_{2}
$$

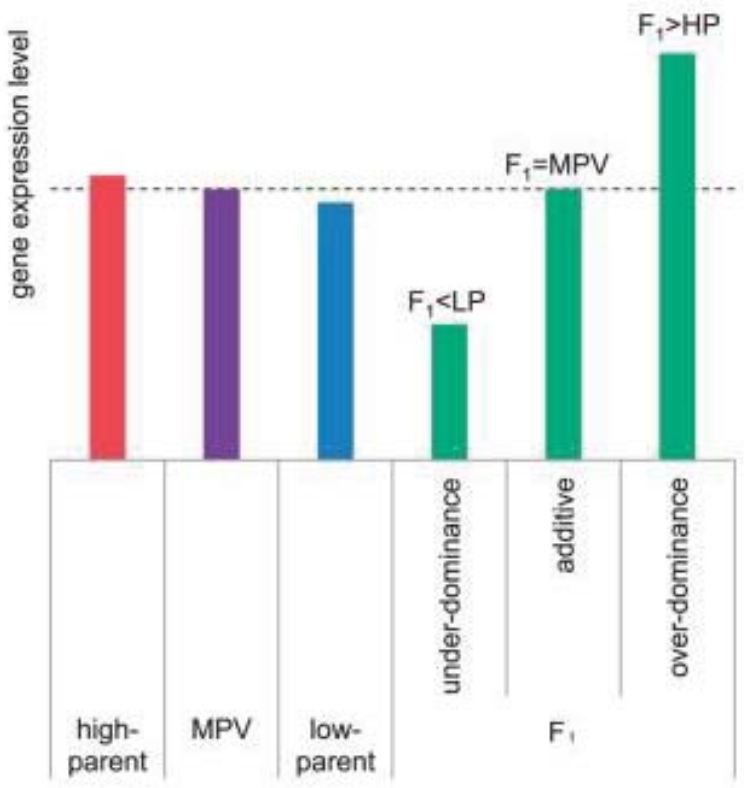

$\mathrm{P}_{1} \neq \mathrm{P}_{2}$

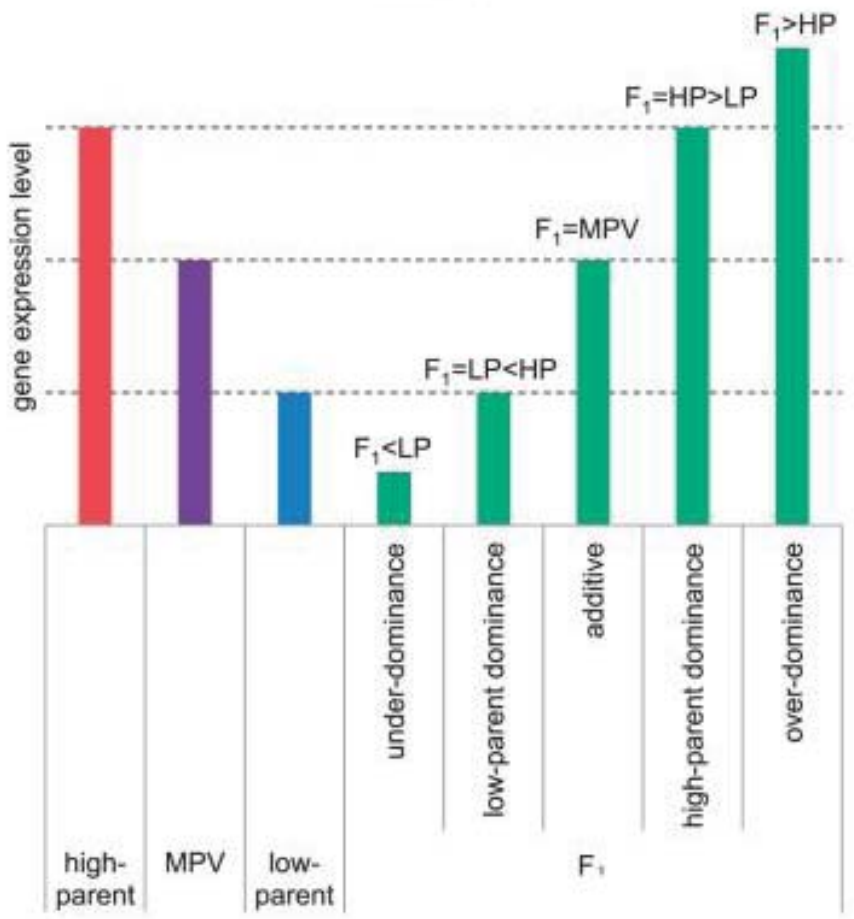

Figure 2: Classification of the mode of gene action in $F_{1}$ hybrid $\left(F_{1}\right)$ compared with parental gene expression level $\left(P_{1}\right.$ or $\left.P_{2}\right)$. Where, LP; low parent, HP; high parent, MPV; mid-parent value.

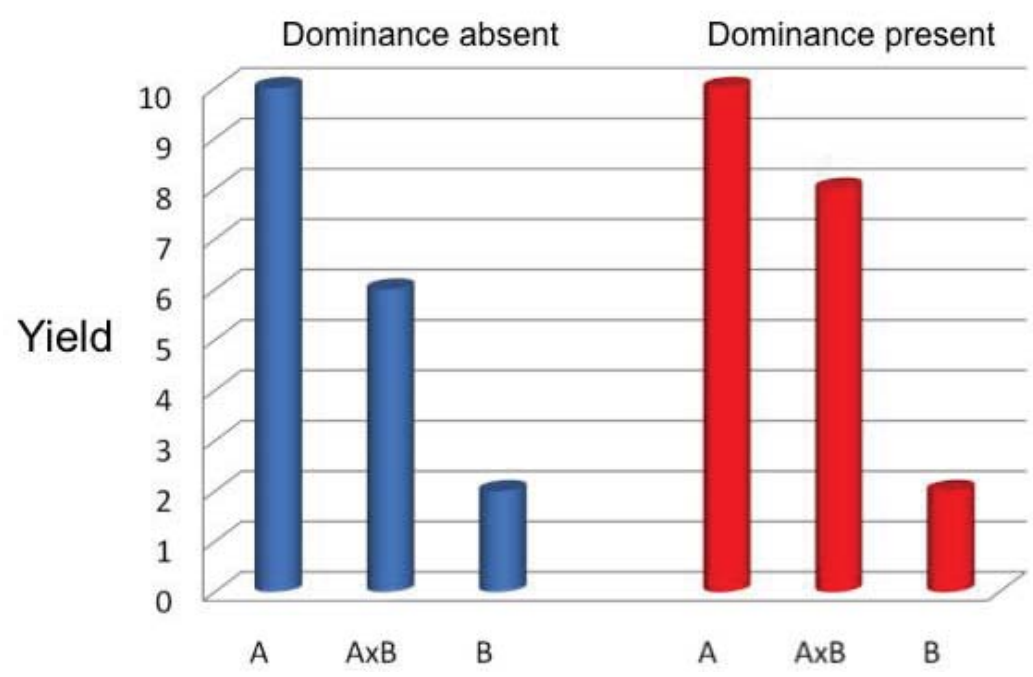

Figure 3: Principle of dominance for the given traits.

phenomena in which the offspring of different types of a species or crosses between species have higher biomass, development speed, and fertility than both parents. To explain heterosis, various theories have been proposed, including dominance, overdominance, and pseudo-over dominance. Heterosis, which manifests as outbreeding enhancement and the polar opposite of inbreeding depression, is important for enhancing crop plant productivity by crossing unrelated genotypes. When two populations of a species with distinct recessive harmful alleles cross, the likelihood of the hybrid being homozygous for the same detrimental genes is unlikely. Due to the masking of recessive harmful genes by a dominant one, the offspring will be more fit than either parent. When the children are allowed to mate at random in succeeding generations, the detrimental alleles will segregate out according to Mendelian inheritance, resulting in individuals with homozygous deleterious alleles who are less fit. However, because the frequency of each detrimental allele would be reduced through mixing, the population's mean level of fitness would still be higher than either parental population.

Heterosis refers to the superiority of hybrids over 
their parents. The heterotic grouping of parental lines and identification of their combining ability aided in the selection of parents and breeding tactics for effective hybrid creation. Planning crosses in breeding programs requires heterotic grouping based on combining ability, genetic performance, and genetic relationship for qualities of interest among germplasm. The term "heterotic pattern" refers to a pair of heterotic groups that exhibit strong heterosis and, as a result, high hybrid performance in their cross. The partition of material available in a hybrid breeding program into at least two divergent populations, which are improved via inter-population selection procedures, is referred to as heterotic patterns. Heterotic patterns have a significant impact on crop development because they heavily influence the type of germplasm used in hybrid breeding programs over time. The heterotic pattern is an important consideration when using germplasm to improve the performance of population crossings and derived hybrids. Finally, the most significant breeding processes for developing the best and attractive varieties for the qualities of interest are combining ability and heterosis.

\section{References}

1. Sprague GF, Tatum LA (1942) General vs. specific combining ability in single crosses of corn. J Am Soci Agronom 34: 923-932. Link: https://bit.ly/3pmp0oc

2. Kempthorne O (1957) An introduction to genetic statistics. Wiley. Link: https://bit.ly/3qofss9

3. Ishaq M, Raziuddin (2016) Combining ability analysis for maturity and plant architecture traits in intra-specific crosses of Rape-seed (Brassica napus L). Sarhad J Agric 32:168-176. Link: https://bit.ly/3Ero2Ln

4. Pal AK, Prodhan HS (1994) Combining ability analysis of grain yield and oil content along with some other attributes in maize (Zea mays L.). Indian $\mathrm{J}$ Genet 54: 376-380. Link: https://bit.ly/3pkK7He

5. Ali Q, Ali A, Awan MF, Tariq M, Ali S, et al. (2014) Combining ability analysis for various physiological, grain yield and quality traits of Zea mays L. Life Sci J 11 540-551. Link: https://bit.ly/3egyVoX

6. Gupta DK, Acharya S, Patel JB (2011) Combining ability and heterosis studies in pigeonpea using A2 cytoplasm from Cajanus scarabaeoides as source of male sterility. J Food Legumes 24: 58-64. Link: https://bit.ly/30S01hj

7. Singh AK, Pan RS, Bhavana P (2013) Heterosis and combining ability analysis in bittergourd (Momordica charantia L.). Bioscan 8: 1533-1536. Link: https://bit.ly/3EmgJEQ

8. Rojas BA, Sprague F (1952) A Comparison of Variance Components in Corn Yield Trials: III. General and Specific Combining Ability and Their Interaction with Locations and Years 1. Agron J 44: 462-466. Link: https://bit.ly/32sVqo3

9. Acquaah G (2012) Principles of plant genetics and breeding. 2nd ed. WileyBlackwell, Oxford. Link: https://bit.ly/3FnBQbj

10. Gouda G, Sabarinathan S, Gupta MK, Donde R, Dash GK, et al. (2021) Quantitative Trait Locus Mapping in Rice. In Applications of Bioinformatics in Rice Research 55-82. Link: https://bit.ly/3EIVmDQ

11. Sincik M, Goksoy AT, Turan MZ (2011) The heterosis and combining ability of diallel crosses of rapeseed inbred lines. Notulae Botanicae Horti Agrobotanici Cluj-Napoca 39: 242-248. Link: https://bit.ly/3yQqLwM

12. Zhang X, Lv L, Lv C, Guo B, Xu R (2015) Combining ability of different agronomic traits and yield components in hybrid barley. PloS One 10: e0126828. Link: https://bit.ly/3ySlswR
13. Rehman MS, Khan MS (2009) Genetic diversity of Hariana and Hissar cattle from Pakistan using microsatellite analysis. Pak Vet J 29: 67-71. Link: https://bit.ly/3JdCmuH

14. Selvaraj $\mathrm{Cl}$, Nagarajan $\mathrm{P}$, Thiyagarajan $\mathrm{K}$, Bharathi $\mathrm{M}$, Rabindran $\mathrm{R}$ (2011) Genetic diversity analysis aiding in selection of parents by RAPD markers in rice (Oryza sativa L). Electronic J Plant Breed 2: 165-178. Link: https://bit.ly/33HMUls

15. Beck DL, Vasal SK, Crossa J (1990) Heterosis and combining ability of CIMMYT's tropical early and intermediate maturity maize (Zea mays L.) germplasm. Maydica 279-385. Link: https://bit.ly/3ss3Qa1

16. Charlesworth D, Willis JH (2009) The genetics of inbreeding depression. Nat Rev Genet 10: 783-796. Link: https://bit.ly/3elfn2y

17. Melchinger AE, Gumber RK (1998) Overview of heterosis and heterotic groups in agronomic crops. Concepts Breeding Heterosis Crop Plants 25: 29-44. Link: https://bit.ly/3H3Y7va

18. Reif JC, Melchinger AE, Xia XC, Warburton ML, Hoisington DA, et al. (2003) Use of SSRs for establishing heterotic groups in subtropical maize. Theor Appl Genet 107: 947-957. Link: https://bit.ly/3mspV4i

19. Stephens JC, Holland PF (1954) Cytoplasmic male sterility for hybrid sorghum seed production. Agron J 46: 20-23. Link: https://bit.ly/3qkIQQX

20. Sawadogo N, Nebie B, Kiebre M, Kando PB, Nanema RK, et al. (2014) Caractérisation agromorphologique des sorghos à grains sucrés (Sorghum bicolor (L.) Moench) du Burkina Faso. Int J Biol Chem Sci 8: 2183- 2197. Link: https://bit.ly/3qlJa0Q

21. Billot C, Ramu P, Bouchet S, Chantereau J, Deu M, et al. (2013) Massive sorghum collection genotyped with SSR markers to enhance use of global genetic resources. Plos One 8:1-16. Link: https://bit.ly/3ejb33Y

22. Ramu P, Billot C, Rami JF, Senthilvel S, Updahyaya HD, et al. (2013) Assessment of genetic diversity in the sorghum reference using EST-SSR markers. Theory Appl Genet 126: 2051-2064. Link: https://bit.ly/3eh8sr4

23. Mindaye TT (2016) Genetic differentiation, heterotic performance and grain yield determinate traits of locally adapted sorghum genotypes in contrasting environments in Ethiopia. Link: https://bit.ly/3EkqfZ1

24. Mathur PN, Mathur JR (1983) Combining ability for yield and its components in pearl millet. Indian J Genet Plant Breed 43: 299-303. Link: https://bit.ly/3Fj9jn8

25. Falconer DS, Mackay TFC (1981) Introduction to quantitative genetics. Link: Link: https://bit.ly/3JgR5oW

26. Wilson ND, Weibel DE, McNew RW (1978) Diallel Analyses of Grain Yield, Percent Protein, and Protein Yield in Grain Sorghum 1. Crop Sci 18: 491-495. Link: https://bit.ly/3FpRUJo

27. Sharma BB, Sharma VK, Dhakar MK, Punetha S (2013) Combining ability and gene action studies for horticultural traits in garden pea: A review. Afr J Agric Res 8: 4718-4725. Link: https://bit.ly/3egzhf1

28. Fasahat P, Rajabi A, Rad JM, Derera J (2016) Principles and utilization of combining ability in plant breeding. Biomet Biostatist Int $\mathrm{J}$ 4: 1-24. Link: https://bit.ly/3FnBbXn

29. Rajendrakumar P, Hariprasanna K, Seetharama N (2015) Prediction of heterosis in crop plants-status and prospects. J Exp Agric Int 9: 1-16. Link: https://bit.ly/33M3ReB

30. Yingzhong Z (1999) Combining ability analysis of agronomic characters in sesame. Inst Sustainable Agric (IAS), CSIC.

31. Ingle KP, Gahukar SJ, Khelurkar VC, Ghorade RB, Kalpande VV, et al. (2018) Heterosis and Combining Ability for Grain Yield Trait in Rabi Sorghum [Sorghum bicolor (L.) Moench] Using Line x Tester Mating Design. Int J Curr Microbiol App Sci 1: 1925-1934. Link: https://bit.ly/3mv2wQ1 
32. Bruce G (1956) Concept of general and specific combining ability in relation to diallel crossing systems. Austra J biolog Sci 9: 463-493. Link: https://bit.ly/3pjtPyy

33. Salgotra RK, Gupta BB, Singh P (2009) Combining ability studies for yield and yield components in Basmati rice. Oryza 46: 12-16. Link: https://bit.ly/3mrLp1r

34. Singh KB, Malhotra RS, Halila MH, Knights EJ, Verma MM (1993) Current status and future strategy in breeding chickpea for resistance to biotic and abiotic stresses. Euphytica 73: 137-149. Link: https://bit.ly/3qncHHc

35. Machado CDF, Santos JBD, Nunes GHDS, Ramalho MAP (2002) Choice of common bean parents based on combining ability estimates. Genet Mol Biol 25: 179-183. Link: https://bit.ly/33M1okh

36. Bernardo R (2014) Breeding for quantitative traits in plants. Woodbury, MN: Stemma press 1: 369 .

37. Kargbo SS, Showemimo F, Akintokun P, Porbeni J (2019) Combining ability analysis and gene action for yield and yield related traits in rice (Oryza sativa L.) under saline conditions. J Plant Breed Genet 7: 63-74. Link: https://bit.ly/3plDODv

38. Pradhan SK, Singh S (2008) Combining ability and gene action analysis for morphological and quality traits in basmati rice. Oryza-An International Journal on Rice 45: 193-197. Link: https://bit.ly/3ek04pk

39. Gopikannan M, Ganesh SK (2013) Investigation on combining ability and heterosis for sodicity tolerance in rice (Oryza sativa L.). Afr J Agric Res 8 4326-4333. Link: https://bit.ly/3FzD8Qk

40. Patial M, Pal D, Kumar J (2016) Combining ability and gene action studies for grain yield and its component traits in barley (Hordeum vulgare L.). SABRAO J Breed Genet 48. Link: https://bit.ly/3ySl69v

41. Grami B, Stefansson BR, Baker RJ (1977) Genetics of protein and oil content in summer rape: heritability, number of effective factors, and correlations. Can $J$ Plant Sci 57: 937-943. Link: https://bit.ly/3egygDZ

42. Viana JMS, Matta FDP (2003) Analysis of general and specific combining abilities of popcorn populations, including selfed parents. Genet Mol Biol 26 465-471. Link: https://bit.ly/3yS9Bii

43. Shull GH (1914) A peculiar negative correlation in Oenothera hybrids. J Genet 4: 83. Link: https://bit.ly/3FnB6D3

44. Duvick DN (2001) Biotechnology in the 1930s: the development of hybrid maize. Nat Rev Genet 2: 69-74. Link: https://bit.ly/3FuAaNm

45. Hochholdinger F, Hoecker N (2007) Towards the molecular basis of heterosis. Trends Plant Sci 12: 427-432. Link: https://bit.ly/3FoKoyE

46. Hallauer AR, Carena MJ, Miranda Filho JB (2010) Heterosis. In Quantitative Genetics in Maize Breeding 477-529. Link: https://bit.ly/3yQqh9W

47. Blum A, Haussmann BIG, Obilana AB, Ayiecho PO, Schipprack W, et al. (2006) Hybrid performance of sorghum and its relationship to morphological and physiological traits under variable drought stress in Kenya. Plant Breed 117: .223-229. Link: https://bit.ly/3eipB3P

48. Peterson CJ (1969) Genotype-environment interaction in winter wheat F progeny.

49. Virmani SS (1994) Prospects of hybrid rice in the tropics and subtropics Hybrid rice technology: New developments and Future Prospects 7-19. Link: https://bit.ly/3qjjuZ9

50. Badu-Apraku B, Oyekunle M, Fakorede MAB, Vroh I, Akinwale RO, et al. (2013) Combining ability, heterotic patterns and genetic diversity of extra-early yellow inbreds under contrasting environments. Euphytica 192: 413-433. Link: https://bit.ly/3EmzoR3
51. Akinwale RO, Badu-Apraku B, Fakorede MAB, VrohBi I (2014) Heterotic grouping of tropical early maturing maize inbred lines based on combining ability in Striga-infested and Striga-free environments and the use of SSR markers for genotyping. Field Crops Res 156: 48-62. Link: https://bit.ly/3sriSN

52. Fan XM, Zhang YM, Yao WH, Chen HM, Tan J, et al. (2009) Classifying maize inbred lines into heterotic groups using a factorial mating design. Agron $\mathrm{J} 101$ 106-112. Link: https://bit.ly/3eg9pQz

53. Dao A, Sanou J, Gracen V, Danquah EY (2014) Heterotic relationship between INERA, CIMMYT and IITA maize inbred lines under drought and well-watered conditions. Maydica 59: 201-210. Link: https://bit.ly/3yW4nCf

54. Nyaligwa L (2016) Genetic diversity analysis of elite maize inbred lines of diverse sources using SSR markers. Maydica 60: 1-8.

55. Reif JC, Gumpert FM, Fischer S, Melchinger AE (2007) Impact of interpopulation divergence on additive and dominance variance in hybrid populations. Genet 176: 1931-1934. Link: https://bit.ly/32izsnT

56. Fato P, Derera J, Tongoona P, Makanda I, Sibiya J (2012) Heterotic orientation of tropical maize inbred lines towards populations ZM523 and Suwan-1 under downy mildew infestation. Euphytica 187: 381- 392. Link: https://bit.ly/3ssd0mU

57. Nepir G, Gissa DW, Zeleke H (2015) Heterosis and combining ability of highland quality protein maize inbred lines. Maydica 60 . Link: https://bit.ly/32mbbxh

58. Lamkey KR, Edwards JW (1999) Quantitative genetics of heterosis. Genetics and Exploitation of Heterosis in Crops 31-48. Link: https://bit.ly/3sJ75dx

59. Flint-Garcia SA, Buckler ES, Tiffin P, Ersoz E, Springer NM (2009) Heterosis is prevalent for multiple traits in diverse maize germplasm. PloS One 4: e7433. Link: https://bit.ly/3qiue3q

60. Reif JC, Hamrit S, Heckenberger M, Schipprack W, Maurer HP, et al. (2005) Trends in genetic diversity among European maize cultivars and their parenta components during the past 50 years. Theor Appl Genet 111: 838-845. Link: https://bit.ly/3Jfd4wc

61. Davenport CB (1908) Determination of dominance in Mendelian inheritance. Proceedings of the American philosophical Society 47: 59-63. Link: https://bit.ly/3ys3cDW

62. Bruce AB (1910) The Mendelian theory of heredity and the augmentation of vigor. Sci 32: 627- 628. Link: https://bit.ly/3srzog6

63. Jones DF (1917) Dominance of linked factors as a means of accounting for heterosis. Genet 2: 466-479. Link: https://bit.ly/3J8NCZv

64. Collins GN (1921) Dominance and the vigor of first generation hybrids. Am Natural 55: 116-133. Link: https://bit.ly/33M11Gp

65. East EM (1908) Suggestions concerning certain bud variations. Plant World 11: 77-83. Link: https://bit.ly/3JfoEYr

66. Shull GH (1908) A new Mendelian ratio and several types of latency. Am Natural 42: 433-451. Link: https://bit.ly/3JdBS7R

67. Piepho HP (2009) Ridge regression and extensions for genomewide selection in maize. Crop Sci 49: 1165-1176. Link: https://bit.ly/32tsoV8

68. Quinby JR, Liang GH (1969) Leaf number and duration to floral initiation and flowering of sorghum parents and hybrids. Can J Genet Cytol 11: 275-280. Link: https://bit.ly/32jzax2

69. Schrag TA, Möhring J, Maurer HP, Dhillon BS, Melchinger AE, et al. (2009) Molecular marker-based prediction of hybrid performance in maize using unbalanced data from multiple experiments with factorial crosses. Theor Appl Genet 118: 741-751. Link: https://bit.ly/3pjPOp1 